\title{
Detection of SARS-Coronavirus in the LightCycler by 5 '-Nuclease Real-Time RT-PCR
}

\author{
Christian Drosten*
}

\section{Introduction}

The severe acute respiratory syndrome (SARS) is a recently discovered viral disease that involves an initial febrile phase followed by interstitial pneumonia and respiratory distress syndrome, leading to death in a fraction of patients. The case fatality proportion ranges from $13.2 \%$ in patients below 60 years of age and $43.3 \%$ in those above 60 (1). The first outbreak of SARS started in southern China in autumn 2002 and spread to several countries of the northern hemisphere until it came to rest in Juli 2003.

The causative agent of SARS has been identified to be a novel coronavirus (SARS-CoV) $(2-4,6)$. The virus seems to be highly contagious and environmentally stable.

Since antibodies are detectable only late in the disease (5), RT-PCR is the most promising method for diagnosing early acute cases. SARS-CoV can be detected best in respiratory samples and stool. Deep respiratory specimens, like sputum or endotracheal aspirates, contain the highest concentration of virus (2), but sampling goes along with the danger of producing infectious aerosols in the hospital. Swab specimens from the nasal cavity or the pharynx seem to contain less virus, but sampling is also a lot less dangerous. Stool samples are equally or more efficient than respiratory samples after day 10 of the disease (5), but they require special treatment to remove RT-PCR inhibitors.

From what is known by now, the sensitivity of RT-PCR is not sufficient to completely rule out the disease in patients presenting early after the onset of symptoms (5). Patients that match the clinical criteria of SARS should be repeatedly tested by RT-PCR after some days of symptoms, and suspects have to be formally ruled out after three or more weeks from the beginning of fever by serology.

This chapter describes two thoroughly evaluated real-time RT-PCR protocols for SARS-CoV. They can be used to achieve a valid confirmation of SARS in compliance with the guidelines issued by WHO during the 2003 SARS epidemic (refer to Text Box 1). Positive findings in either assay can be cross-confirmed by the other. Please note that these guidelines will be subject to change in the future to meet the requirements of non-epidemic settings.

\footnotetext{
* Christian Drosten, Bernhard-Nocht Institute for Tropical Medicine, Hamburg, Germany E-mail: drosten@bni-hamburg.de
} 


\section{Text Box 1}

\section{WHO guidelines for confirming SARS by RT-PCR}

Laboratories willing to use RT-PCR to confirm SARS should realize that it has been made mandatory by WHO to confirm positive findings by repeating the test

- from another clinical sample type of the same patient (e.g., respiratory sample and stool), or

- from the same sample type drawn at a different point of time, or

- from the same sample with an assay targeting another genomic region.

Ideally, two or more tests targeting different genomic regions should always be applied

\section{Materials}

Equipment LightCycler Instrument (Roche Diagnostics, Mannheim, Germany) LightCycler Reaction Capillaries (Roche Diagnostics, Mannheim, Germany) LightCycler software version 3.5 (Roche Diagnostics, Mannheim, Germany) Primer Express (Applied Biosystems, Weiterstadt, Germany)

Reagents Amplification primers (Tib-Molbiol, Berlin, Germany) Hybridization probes (Tib-Molbiol, Berlin, Germany) Superscript II reverse transcriptase/Platinum Taq polymerase one-step RT-PCR kit (Invitrogen, Karlsruhe, Germany) Megascript T7 Kit (Ambion, Austin, Texas) pCRII Topo TA Cloning Kit (Invitrogen, Karlsruhe, Germany)

Text Box 2

\section{SARS-CoV positive control}

A gamma-irradiated, non-infectious, full virus positive control preparation is available for diagnostic laboratories from WHO. Please enquire at WHO for distributors. In many countries, positve controls are available through national influenza reference laboratories.

\section{Procedure}

Preparation of Template DNA

Oligonucleotides and Reagent Formulations Protocol A
Template RNA was prepared in a biosafety level 3 laboratory as described in Table 1.

RNA solutions were stored at $8^{\circ} \mathrm{C}$ until further processing. $5 \mu$ l portions were lateron analyzed in PCR.

Protocol A has originally been published in connection with the identification of the causative agent (2). It targets the replicase gene in open reading frame $1 \mathrm{~b}$ of SARS-CoV, the only genomic region of SARS-CoV known at that point of time. 
Table 1. Preparation of clinical specimens for RT-PCR detection of SARS-coronavirus

\begin{tabular}{|c|c|c|}
\hline $\begin{array}{l}\text { Sputum and endotracheal } \\
\text { aspirates }\end{array}$ & Swab specimen & Stool specimens \\
\hline $\begin{array}{l}\text { Use native sputum or } \\
\text { endotracheal aspirate } \\
\text { specimens } \\
\text { Mix with equal volume of } \\
2 \text { X NACC buffer } \\
\text { Slowly shake for } 30 \mathrm{~min}\end{array}$ & $\begin{array}{l}\text { Use native swabs containing } \\
\text { no preservatives or trans- } \\
\text { portmedia (e.g., Q-Tips } \\
\text { whetted with one drop of } \\
0.9 \% \mathrm{NaCl} \text { ) }\end{array}$ & $\begin{array}{l}\text { Use } 200 \mathrm{mg} \text { or } 200 \mu \mathrm{l} \text { native } \\
\text { stool specimens }\end{array}$ \\
\hline $\begin{array}{l}\text { Add } 140 \mu \mathrm{l} \text { of homogenate } \\
\text { to } 560 \mu \mathrm{l} \text { of buffer AVL } \\
\text { (Viral RNA mini kit, Qiagen) } \\
\text { Proceed according to manu- } \\
\text { facturer's instructions }\end{array}$ & $\begin{array}{l}\text { Dip whole swab into } 560 \mu \mathrm{l} \\
\text { of buffer AVL (Viral RNA } \\
\text { mini kit, Qiagen) } \\
\text { Add } 500 \mu \text { l Ethanol abs. } \\
\text { Proceed according to manu- } \\
\text { facturer's instructions }\end{array}$ & $\begin{array}{l}\text { Treat samples exactly accord- } \\
\text { ing to manufacturer's instruc- } \\
\text { tions, Qiagen DNA stool mini } \\
\text { kit, protocol for isolation of } \\
\text { DNA from stool for pathogen } \\
\text { detection }\end{array}$ \\
\hline \multicolumn{2}{|c|}{$\begin{array}{l}\text { Elute RNA from column with } 60 \mu \mathrm{l} 80^{\circ} \mathrm{C} \text { elution buffer } \\
\text { (AVE, included in the kit) }\end{array}$} & $\begin{array}{l}\text { Elute RNA from column with } \\
200 \mu \mathrm{l} 80^{\circ} \mathrm{C} \text { elution buffer } \\
\text { (AE, included in the kit) }\end{array}$ \\
\hline
\end{tabular}

${ }^{\mathrm{a}} 1 \% \mathrm{~N}$-acetylcysteine, $0.9 \% \mathrm{NaCl}$, in double-destilled water

Like in other RNA viruses, the polymerase/replicase gene of SARS-CoV is highly conserved between different isolates (8) and can thus be considered a reliable RT-PCR target. The assay uses a $5^{\prime}$-nuclease probe, a detection format chosen in the intention of extending the compatibility of the protocol to real-time PCR instruments other than the LightCycler. The assay described in protocol A is the basis of the first commercial RT-PCR kit for the virus. The analytical sensitivity of the protocol is the same as that of the kit, but the kit in addition contains an internal control.

Protocol A. Replicase gene RT-PCR assay for detection of SARS-coronavirus

\begin{tabular}{llll} 
Oligonucleotides replicase gene assay & & \\
$\begin{array}{l}\text { Name } \\
\text { Function }\end{array}$ & $\begin{array}{l}\text { Genome position } \\
\text { SARS-CoV Urbani } \\
\text { Acc. AY278741 }\end{array}$ & $\begin{array}{l}\text { Sequence } \\
5^{\prime} \rightarrow 3^{\prime}\end{array}$ & $\mathrm{T}_{\mathrm{m}}\left({ }^{\circ} \mathrm{C}\right)$ \\
\hline $\begin{array}{l}\text { BNITMSARS1 } \\
\text { Forward primer }\end{array}$ & $18187-18206$ & TTATCACCCGCGAAGAAGCT & 63.5 \\
$\begin{array}{l}\text { BNITMSARAS2 } \\
\text { Reverse primer }\end{array}$ & $18243-18264$ & CTCTAGTTGCATGACAGCCCTC & 62.7 \\
$\begin{array}{l}\text { TMSARP1 } \\
\text { Probe }\end{array}$ & $18218-18241$ & FAM-TCGTGCGTGGATTGGCTT- & 73.0 \\
& & TGATGT-TAMRA &
\end{tabular}




\begin{tabular}{lll} 
Formulation replicase gene assay & & \\
\hline Component & Stock concentration & Volume per reaction \\
\hline $\begin{array}{l}\text { Reaction mix (Superscript II/ } \\
\text { Platinum Kit, Invitrogen) }\end{array}$ & $2.5 \mathrm{X}$ & $12.5 \mu \mathrm{l}$ \\
Non-acetylated BSA $_{\mathrm{MgSO}_{4}}$ & $1 \mathrm{mg} / \mathrm{ml}$ & $1 \mu \mathrm{l}$ \\
BNITMSARS1 $_{\text {BNITMSARAS2 }}$ & $50 \mathrm{mM}$ & $1.2 \mu \mathrm{l}$ \\
BNITMSARP & $10 \mu \mathrm{M}$ & $0.5 \mu \mathrm{l}$ \\
RT/Taq Mixture (Superscript II/ & $10 \mu \mathrm{M}$ & $0.5 \mu \mathrm{l}$ \\
Platinum Kit, Invitrogen) & $10 \mu \mathrm{M}$ & $0.6 \mu \mathrm{l}$ \\
$\mathrm{H}_{2} \mathrm{O}$ (PCR grade) & & $0.6 \mu \mathrm{l}$ \\
RNA solution & - & $3.1 \mu \mathrm{l}$ \\
\hline
\end{tabular}

Protocol B Protocol B targets the nucleocapsid (N) gene of SARS-CoV and uses the same reagents as protocol $A$. It can be used to achieve a valid confirmation of SARS in compliance with the guidelines issued by WHO during the 2003 SARS epidemic (refer to Text Box 1). Use of the $\mathrm{N}$ gene was based on the reportedly higher abundance of such subgenomic RNA in infected cells, possibly leading to an increased detection sensitivity. However, in a preliminary study described below, it appeared that the assay is not more sensitive than the one described in Protocol A. Protocol B uses $5^{\prime}$-nuclease probes for the same reasons as stated above.

Protocol B. Nucleoprotein gene RT-PCR assay for detection of SARS coronavirus

\begin{tabular}{llll}
\multicolumn{4}{l}{ Oligonucleotides nucleoprotein gene assay } \\
$\begin{array}{l}\text { Name } \\
\text { Function }\end{array}$ & $\begin{array}{l}\text { Genome position } \\
\text { SARS-CoV Urbani } \\
\text { Acc. AY278741 }\end{array}$ & $\begin{array}{l}\text { Sequence } \\
5^{\prime} \rightarrow 3^{\prime}\end{array}$ & $\mathrm{T}_{\mathrm{m}}\left({ }^{\circ} \mathrm{C}\right)$ \\
\hline $\begin{array}{l}\text { SANS1 } \\
\text { Forward primer }\end{array}$ & $28176-28196$ & TGGACCCACAGATTCAACTGA & 62.7 \\
$\begin{array}{l}\text { SANAs2 } \\
\text { Reverse primer }\end{array}$ & $28265-28286$ & GCTGTGAACCAAGACGCAGTAT & 63.0 \\
$\begin{array}{l}\text { SANP } \\
\text { Probe }\end{array}$ & $28200-28223$ & FAM-TAACCAGAATGGAGGACG- & \\
\hline
\end{tabular}




\section{Formulation nucleoprotein gene assay}

\begin{tabular}{lll} 
Component & Stock concentration & Volume per reaction \\
\hline $\begin{array}{l}\text { Reaction mix (Superscript II/ } \\
\text { Platinum Kit, Invitrogen) }\end{array}$ & $2.5 \mathrm{X}$ & $12.5 \mu \mathrm{l}$ \\
Non-acetylated BSA $_{\mathrm{MgSO}_{4}}$ & $1 \mathrm{mg} / \mathrm{ml}$ & $1 \mu \mathrm{l}$ \\
$\mathrm{SANS}$ & $50 \mathrm{mM}$ & $1.2 \mu \mathrm{l}$ \\
SANAs2 & $10 \mu \mathrm{M}$ & $0.5 \mu \mathrm{l}$ \\
SANP & $10 \mu \mathrm{M}$ & $1 \mu \mathrm{l}$ \\
RT/Taq Mixture (Superscript II/ & $10 \mu \mathrm{M}$ & $0.5 \mu \mathrm{l}$ \\
Platinum Kit, Invitrogen) & as provided & $0.5 \mu \mathrm{l}$ \\
$\mathrm{H}_{2} \mathrm{O}$ (PCR grade) & - & $2.8 \mu \mathrm{l}$ \\
RNA solution & - & $5 \mu \mathrm{l}$ \\
\hline
\end{tabular}

Master mixes of the described reaction mixtures were freshly prepared, containing all reaction components except the $5 \mu \mathrm{l}$ of RNA solution. The master mix was then distributed in volumes of $20 \mu \mathrm{l}$ into LightCycler reaction capillaries, $5 \mu \mathrm{l}$ of RNA solution were added, and the content of each capillary was spun down by a brief centrifugation step after capping. For each patient RNA solution to be tested, a parallel reaction was prepared, containing the same $5 \mu$ l of RNA solution and the same $20 \mu \mathrm{l}$ of reaction mix. To allow detection of substances interfering with PCR amplification (PCR inhibitors), an additional $1 \mu \mathrm{l}$ of an RNA run control solution was added. The run control solution had previously been prepared by end-point dilution of a high-titered RNA extract. The concentration of the runcontrol solution was adjusted to range $1.5 \log 10$ above the detection end point of that dilution series. The resulting solution was then stored in small aliquots at $-20^{\circ} \mathrm{C}$ for subsequent use.

Capillaries were placed in a LightCycler Carousel and subjected to thermal cycling as follows. 
Protocol A Thermal cycling profile for replicase gene RT-PCR assay (Protocol A)

\begin{tabular}{|c|c|c|}
\hline Parameter & Value & \\
\hline \multicolumn{3}{|l|}{ Reverse transcription } \\
\hline \multirow[t]{2}{*}{ Cycles } & \\
\hline & \multicolumn{2}{|l|}{ Segment 1} \\
\hline Target temperature $\left[{ }^{\circ} \mathrm{C}\right]$ & \multicolumn{2}{|l|}{$45^{\circ} \mathrm{C}$} \\
\hline Incubation time [min] & \multicolumn{2}{|l|}{20} \\
\hline Temperature transition rate $\left[{ }^{\circ} \mathrm{C} / \mathrm{s}\right]$ & \multicolumn{2}{|l|}{20} \\
\hline Acquisition mode & \multicolumn{2}{|l|}{ none } \\
\hline Gains & \multicolumn{2}{|l|}{ Automatic } \\
\hline \multicolumn{3}{|l|}{ Denaturation } \\
\hline \multirow[t]{2}{*}{ Cycles } & \multicolumn{2}{|l|}{1} \\
\hline & \multicolumn{2}{|l|}{ Segment 1} \\
\hline Target temperature $\left[{ }^{\circ} \mathrm{C}\right]$ & \multicolumn{2}{|l|}{$95^{\circ} \mathrm{C}$} \\
\hline Incubation time [min] & \multicolumn{2}{|l|}{3} \\
\hline Temperature transition rate $\left[{ }^{\circ} \mathrm{C} / \mathrm{s}\right]$ & \multicolumn{2}{|l|}{20} \\
\hline Acquisition mode & \multicolumn{2}{|l|}{ none } \\
\hline Gains & \multicolumn{2}{|l|}{ Automatic } \\
\hline \multicolumn{3}{|l|}{ Amplification } \\
\hline \multirow[t]{2}{*}{ Cycles } & \multicolumn{2}{|l|}{40} \\
\hline & Segment 1 & Segment 2 \\
\hline Target temperature $\left[{ }^{\circ} \mathrm{C}\right]$ & 95 & 58 \\
\hline Incubation time [s] & 10 & 30 \\
\hline Temperature transition rate $\left[{ }^{\circ} \mathrm{C} / \mathrm{s}\right]$ & 20 & 20 \\
\hline Acquisition mode & None & Single \\
\hline Gains & Automatic & \\
\hline
\end{tabular}


Thermal cycling profile for nucleocapsid gene RT-PCR assay (Protocol B)

\begin{tabular}{|c|c|c|c|}
\hline Parameter & Value & & \\
\hline \multicolumn{4}{|l|}{ Reverse transcription } \\
\hline Cycles & \multicolumn{3}{|l|}{1} \\
\hline \multicolumn{4}{|l|}{ Segment 1} \\
\hline Target temperature $\left[{ }^{\circ} \mathrm{C}\right]$ & \multicolumn{3}{|l|}{$50^{\circ} \mathrm{C}$} \\
\hline Incubation time [min] & \multicolumn{3}{|l|}{10} \\
\hline Temperature transition rate $\left[{ }^{\circ} \mathrm{C} / \mathrm{s}\right]$ & \multicolumn{3}{|l|}{20} \\
\hline Acquisition mode & \multicolumn{3}{|l|}{ none } \\
\hline Gains & \multicolumn{3}{|l|}{ Automatic } \\
\hline \multicolumn{4}{|l|}{ Denaturation } \\
\hline \multirow[t]{2}{*}{ Cycles } & \multicolumn{3}{|l|}{1} \\
\hline & \multicolumn{3}{|l|}{ Segment 1} \\
\hline Target temperature $\left[{ }^{\circ} \mathrm{C}\right]$ & \multicolumn{3}{|l|}{$95^{\circ} \mathrm{C}$} \\
\hline Incubation time [min] & \multicolumn{3}{|l|}{3} \\
\hline Temperature transition rate $\left[{ }^{\circ} \mathrm{C} / \mathrm{s}\right]$ & \multicolumn{3}{|l|}{20} \\
\hline Acquisition mode & \multicolumn{3}{|l|}{ none } \\
\hline Gains & \multicolumn{3}{|l|}{ Automatic } \\
\hline \multicolumn{4}{|l|}{ Amplification } \\
\hline \multirow[t]{2}{*}{ Cycles } & \multicolumn{3}{|l|}{40} \\
\hline & Segment 1 & Segment 2 & Segment 3 \\
\hline Target temperature $\left[{ }^{\circ} \mathrm{C}\right]$ & 95 & 55 & 72 \\
\hline Incubation time $[\mathrm{s}]$ & 2 & 12 & 10 \\
\hline Temperature transition rate $\left[{ }^{\circ} \mathrm{C} / \mathrm{s}\right]$ & 20 & 20 & 20 \\
\hline Acquisition mode & None & Single & None \\
\hline Gains & Automatic & & \\
\hline
\end{tabular}

Fluorescence in both protocols was read on the F1/F2 channel. A reaction was considered positive when an exponential increase in fluorescent signal was observed, negative when there was no signal in the patient test reaction but a signal in the corresponding inhibition control reaction (spiked with run control solution), and inhibited when there was no signal in the test reaction and the inhibition control reaction. Refer to Text Box 1 for diagnostic implications of results.

Both protocols allowed to quantify the virus RNA concentration (note that the term "viral load" should be reserved for HIV-1 plasma vireamia). To serve as reference standards for real-time RT-PCR quantification, in-vitro transcribed RNA was generated for both target genes by cloning PCR products of each assay into a plasmid vector with the pCRII Topo TA Cloning Kit (Invitrogen, Karlsruhe, Germany), which was then transcribed into RNA by T7 polymerase (Megascript T7 
Kit, Ambion, Austin, Texas). The RNA solutions were photometrically quantified and diluted in double destilled DEPC-treated water containing $25 \mu \mathrm{g} / \mathrm{ml} \mathrm{E}$. coli tRNA as a non-specific carrier. Aliquots were stored at $-80^{\circ} \mathrm{C}$. Dilution series ranging from concentrations of about 10 to 10.000 copies per $140 \mu \mathrm{l}$ were extracted with the Qiagen viral RNA kit and amplified in parallel with the experimental samples to be quantified. The concentrations of the standard solutions were entered in the LightCycler sample sheet. Evaluation then followed the guidelines provided in the LightCycler user's manual for absolute quantification of target genes.

\section{Results}

The analytical sensitivities of both protocols were determined using in-vitro transcribed RNA standards, generated by cloning PCR products of each assay into a plasmid vector that was then transcribed into RNA by T7 polymerase. Replicate reactions containing different amounts of RNA transcripts $(2,4,8$, and 16 copies of RNA per reaction) were conducted, and the results were submitted to probit regression analysis. The replicase and the $\mathrm{N}$ assay, respectively, yielded positive results at a $50 \%$ chance with a theroretical 1.9 or 2.2 copies of RNA per assay, and at a $95 \%$ chance with 2.8 or 3.0 copies per assay. It could therefore be assumed that the tests have equivalent analytical sensitivities.

In clinical samples, an $\mathrm{N}$ gene based test would nevertheless be expected to yield a better sensitivity, since subgenomic $\mathrm{N}$ fragments have been reported to be highly abundant in cells (7). To test this hypothesis, quantitative RT-PCR results from both protocols were compared in a total of 21 samples from 5 patients with SARS. Samples and history of patients A and B have earlier been described in detail (2). Patient $C$ was a male German who had returned to Germany from Hanoi, Vietnam after a business trip. Patients D and E were hospitalized in Hong Kong (samples kindly provided by Dr. John Tam, Chinese University of Hong Kong). Seroconversion in all patients had been demonstrated after convalescence. Quantification was done by co-amplifying a limiting dilution series of in-vitro transcribed RNA standards. The RNA copy number in all samples was equivalent in both assays (Table 2), suggesting that the $\mathrm{N}$ gene assay would not increase the clinical sensitivity in larger patient cohorts.

Figure 1 shows that the RNA quantification results in both assays correlate perfectly $(r=1.0)$.

The replication kinetics of SARS-CoV gives an explanation for these somewhat unexpected findings (Figure 2). The cytoplasma of Vero cells, infected with SARS$\mathrm{CoV}$ at a multiplicity of infection of 0.01 , indeed yielded about 5 times more $\mathrm{N}$ gene RNA than replicase gene RNA on the first day of infection. After a few days, however, levels of both RNAs approximated each other. In the supernatant, abundance of both RNAs was equivalent throughout the infection. If one assumes that infected cells contained in clinical samples are already in a late stage of virus replication, it is therefore no surprise that both target genes yield the same diagnostic outcome in RT-PCR. 
Table 2. Quantitative detection of SARS-CoV in clinical samples

$\begin{array}{ll}\text { Patient } & \text { Virus RNA concentration, copies per sample } \\ \text { Type of sample } & \text { Replicase assay } \quad \text { Nucleocapsid assay }\end{array}$

$$
\text { A }
$$

Nasal swab

$1.2 \times 10^{2}$

$2.5 \times 10^{1}$

Pharyngeal swab

$8.6 \times 10^{2}$

$8.5 \times 10^{2}$

Sputuma

$5.5 \times 10^{6}$

$6.1 \times 10^{6}$

Plasma

$5.5 \times 10^{2}$

$7.8 \times 10^{2}$

Stool ${ }^{\text {b }}$

$1.6 \times 10^{3}$

$1.6 \times 10^{3}$

Broncho-alveolar lavage

$1.7 \times 10^{5}$

$2.9 \times 10^{5}$

Pharyngeal swab, late ${ }^{b}$

B

Nasal swab

$7.4 \times 10^{1}$

$9.8 \times 10^{1}$

Pharyngeal swab

Sputuma

$-$

Plasma

$1.9 \times 10^{4}$

$2.4 \times 10^{4}$

Stool $^{c}$

$6.1 \times 10^{4}$

Pharyngeal swab, late

C

Pharyngeal swab

Serum

Stool $^{d}$

$-$

$6.9 \times 10^{4}$

Broncho-alveolar lavage

Pharyngeal swab, late

Urine $^{\text {d }}$

D

Pharyngeal swab

$7.4 \times 10^{2}$

$1.1 \times 10^{3}$

E

Pharyngeal swab

$1.1 \times 10^{6}$

$1.4 \times 10^{6}$

Patient A. Samples from day 9, unless otherwise stated Patient B. Samples from day 3, unless otherwise stated Patient C. Samples from day 4, unless otherwise stated Patient D. Unknown sampling date

Patient E. Unknown sampling date

a. Specimen prediluted due to limited availability of material

b. After convalescence, day 25

c. After convalescence, day 19

d. After convalescence, day 17 


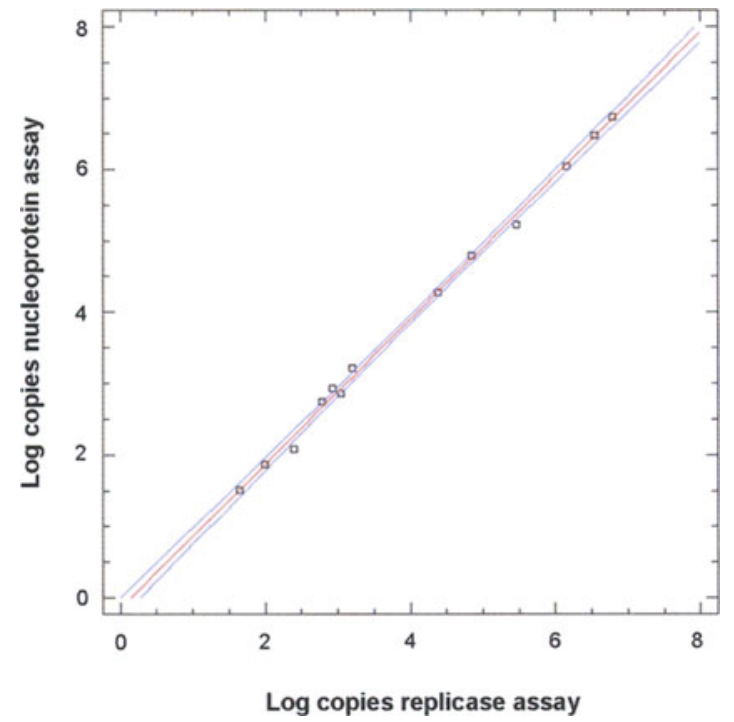

Fig. 1. Virus concentration in 21 Samples from 5 patients with confirmed SARS (refer to Table 2) as determined with replicase and nucleoprotein gene real-time RT-PCR assays. Black squares represent data points, the red line is a linear regression line, the blue lines are $95 \%$ confidence limits of the regression. Statistical evaluation was done with the Statgraphics 5 package, Statistical Graphics, Inc

\section{Comments}

General The absence of an $100 \%$ sensitive laboratory test for SARS, especially in the early phase of the disease, will become a major problem in case management during influenza epidemics. One infectious patient can start a SARS epidemic, but SARS is a very unlikely diagnosis at all. The protocols presented in this chapter enable a fully valid laboratory confirmation of SARS cases by real-time RT-PCR. However, the known pitfalls of PCR diagnostics, like contamination or interpretation errors, are especially critical in this disease; a false positive result can cause tremendous public disconcertment that may have unforseeable adverse effects. In a situation of a low (zero) level of SARS endemicity with other similar diseases prevailing, suspected cases must therefore be handled with utmost care. Positive results should in any case be confirmed by a SARS reference laboratory. Contact WHO for an up-to-date listing of such insitutions.

It is essential to notice that according to experiences with SARS patients in Singapore (Evelyn Koay, National University of Singapore, personal communication) and Germany the virus RNA concentration in clinical specimens declines in the following order: sputum or endotracheal aspirates $>$ stool samples $>$ pharyngeal swabs or saliva. Sampling of sputum and endotracheal aspirates generates infec- 

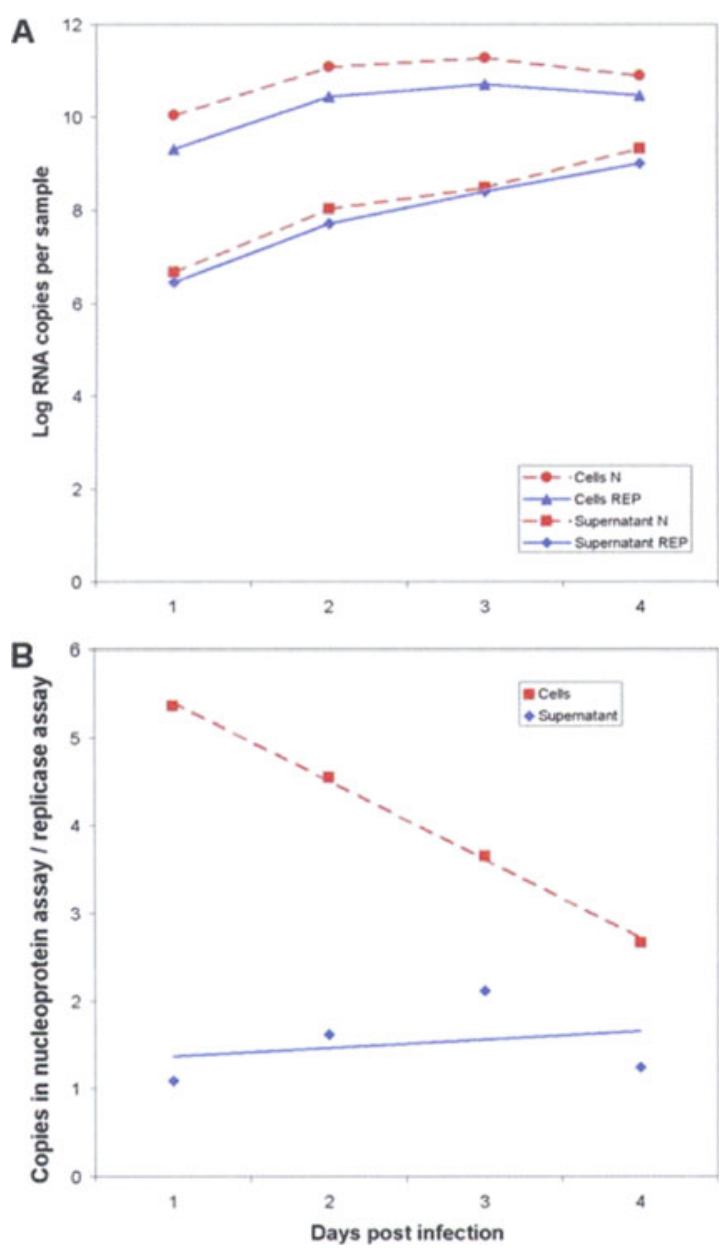

Fig. 2. Accumulation kinetics of SARS-Coronavirus replicase and nucleoprotein genes in Vero cell culture. A. Intracellular copy numbers ("Cells") versus copy numbers in supernatant. REP: replicase gene, $\mathrm{N}$ : nucleoprotein gene. B. Copy numbers of nucleoprotein gene per copy numbers of replicase gene in cells and supernatants

tious aerosols and can therefore be done only in negative pressure isolation units with adequate respiratory protection for health care workers. Stool samples are more appropriate in the later phase of the disease (beyond day 10, (5)).

SARS-CoV is highly contagious, and laboratory-associated infections have already occurred in the past. Note that according to WHO guidelines, biosafety level 2 is required for handling clinical specimens prior to PCR. Manipulations such as virus culture require at least biosafety level 3 . 


\section{References}

1. Donnelly, C. A., A. C. Ghani, G. M. Leung, A. J. Hedley, C. Fraser, S. Riley, L. J. Abu-Raddad, L. M. Ho, T. Q. Thach, P. Chau, K. P. Chan, T. H. Lam, L. Y. Tse, T. Tsang, S. H. Liu, J. H. Kong, E. M. Lau, N. M. Ferguson, and R. M. Anderson. 2003. Epidemiological determinants of spread of causal agent of severe acute respiratory syndrome in Hong Kong. Lancet. 361:1761-6

2. Drosten, C., S. Gunther, W. Preiser, S. van der Werf, H. R. Brodt, S. Becker, H. Rabenau, M. Panning, L. Kolesnikova, R. A. Fouchier, A. Berger, A. M. Burguiere, J. Cinatl, M. Eickmann, N. Escriou, K. Grywna, S. Kramme, J. C. Manuguerra, S. Muller, V. Rickerts, M. Sturmer, S. Vieth, H. D. Klenk, A. D. Osterhaus, H. Schmitz, and H. W. Doerr. 2003. Identification of a novel coronavirus in patients with severe acute respiratory syndrome. N Engl J Med. 348:1967-76

3. Fouchier, R. A., T. Kuiken, M. Schutten, G. van Amerongen, G. J. van Doornum, B. G. van den Hoogen, M. Peiris, W. Lim, K. Stohr, and A. D. Osterhaus. 2003. Aetiology: Koch's postulates fulfilled for SARS virus. Nature. 423:240

4. Ksiazek, T. G., D. Erdman, C. S. Goldsmith, S. R. Zaki, T. Peret, S. Emery, S. Tong, C. Urbani, J. A. Comer, W. Lim, P. E. Rollin, S. F. Dowell, A. E. Ling, C. D. Humphrey, W. J. Shieh, J. Guarner, C. D. Paddock, P. Rota, B. Fields, J. DeRisi, J. Y. Yang, N. Cox, J. M. Hughes, J. W. LeDuc, W. J. Bellini, and L. J. Anderson. 2003. A novel coronavirus associated with severe acute respiratory syndrome. N Engl J Med. 348:1953-66

5. Peiris, J. S., C. M. Chu, V. C. Cheng, K. S. Chan, I. F. Hung, L. L. Poon, K. I. Law, B. S. Tang, T. Y. Hon, C. S. Chan, K. H. Chan, J. S. Ng, B. J. Zheng, W. L. Ng, R. W. Lai, Y. Guan, and K. Y. Yuen. 2003. Clinical progression and viral load in a community outbreak of coronavirus-associated SARS pneumonia: a prospective study. Lancet. 361:1767-72

6. Peiris, J. S., S. T. Lai, L. L. Poon, Y. Guan, L. Y. Yam, W. Lim, J. Nicholls, W. K. Yee, W. W. Yan, M. T. Cheung, V. C. Cheng, K. H. Chan, D. N. Tsang, R. W. Yung, T. K. Ng, and K. Y. Yuen. 2003. Coronavirus as a possible cause of severe acute respiratory syndrome. Lancet. 361:1319-25

7. Rota, P. A., M. S. Oberste, S. S. Monroe, W. A. Nix, R. Campagnoli, J. P. Icenogle, S. Penaranda, B. Bankamp, K. Maher, M. H. Chen, S. Tong, A. Tamin, L. Lowe, M. Frace, J. L. DeRisi, Q. Chen, D. Wang, D. D. Erdman, T. C. Peret, C. Burns, T. G. Ksiazek, P. E. Rollin, A. Sanchez, S. Liffick, B. Holloway, J. Limor, K. McCaustland, M. Olsen-Rasmussen, R. Fouchier, S. Gunther, A. D. Osterhaus, C. Drosten, M. A. Pallansch, L. J. Anderson, and W. J. Bellini. 2003. Characterization of a novel coronavirus associated with severe acute respiratory syndrome. Science. 300:1394-9

8. Ruan, Y. J., C. L. Wei, A. L. Ee, V. B. Vega, H. Thoreau, S. T. Su, J. M. Chia, P. Ng, K. P. Chiu, L. Lim, T. Zhang, C. K. Peng, E. O. Lin, N. M. Lee, S. L. Yee, L. F. Ng, R. E. Chee, L. W. Stanton, P. M. Long, and E. T. Liu. 2003. Comparative full-length genome sequence analysis of 14 SARS coronavirus isolates and common mutations associated with putative origins of infection. Lancet. 361:1779-85 